\title{
Økonomifolk har også et etisk og astetisk samfundsansvar
}

\author{
Af Preben Melander *)
}

Med økonomistyringens faglige tilgang anlægges primært et rationelt og funktionelt perspektiv på styringens design, dens organisatoriske former og arbejdspraksis. Debatten om økonomistyringens teknologiske og metodemæssige anvisninger dominerer i dag såvel forskningen som videnformidlingen på feltet. Fokus ligger her oftest på, hvordan man får $ø$ konomistyringens rationelle opskrifter overført og transformeret til organisationers styringspraksis, ofte anskuet i et beskrivende, institutionelt og evidensbaseret topdown perspektiv. Kun sjældent anskues styringens design og anvendelse som en emergerende konsekvens af organisationers og menneskers mangfoldighed, værdier, refleksioner, relationer, fantasi og kreativitet set med kritiske og humanistiske øjne. Når det sker, er fokus ofte flyttet uden for økonomistyringens faglige regi og udfoldes i ledelses- og organisationsteoriens begrebsdannelser. ${ }^{2}$

\section{A. Indledning}

Man kan godt undre sig over denne ensidige og snævre fokusering på det rationelle, teknologiske og systemmæssige syn på økonomistyringens design og anvendelse, som i sin tankegang er irrationel, urealistisk og naiv i sit fundament. For i virkeligheden er økonomistyringens strategiske betydning, gennemslagskraft og organisatoriske effekter på alle punkter bestemt af menneskers medvirken og engagement gennem såvel deres erkendelse, refleksion, samspil som deres praktiske indsats og sanselighed. Det er en almen erkendelse, at styringsteknologier kun får

*) Preben Melander er professor emeritus i Anvendt Ledelsesteknologi ved CBS 
betydning, hvis de overføres, optages og oversættes til menneskers daglige arbejdspraksis (Søren Obed Madsen 2015). Styring bør i langt højere grad anskues i et humanistisk, psykologisk og socialt perspektiv. For styring er rettet mod menneskers evne til at forholde sig til og håndtere samfundets knappe ressourcer og pådrager dermed såvel fællesskabet som den enkelte et etisk og humanistisk ansvar. Styringen udvikles af mennesker i samspil mellem ledere og medarbejdere. Styring er et resultat af menneskers erkendelse, erfaringer og interaktion, som over tid er nedarvet i form af samfundets og organisationers arbejdssprog, sociale normer og en fælles accept af samfundets forhandlede orden.

I alle disse sammenhænge udgør de afgørende faktorer for succes menneskers involvering, ejerskab, motivation og samspil. Det er en betingelse for, at samfundet kan fungere og hænge sammen. Derfor indebærer økonomistyring mere end rationelle teknologier, tomme systemer og effektive kontrolregimer. Det handler om mennesker og deres værdier, udsyn, relationer, væredygtighed og deres fælles etiske og oplevede ansvarlighed. Forankring af økonomistyring er et spørgsmål om menneskers involvering, samspil og entusiasme. Dette kræver mere end styring og management. Det kræver autentisk lederskab i et åbent samspil. Det er det, vi i dag kalder »samfundslederskabelse«.

Et samfunds samhørighed og fornyelse må bygge på menneskers fantastiske evne til at opsøge, opfange og forstå de overliggende værdiskabende tendenser, som kan få det fokale samfund til at udvikle sig og spille sammen til fællesskabets bedste. Dette sker ikke ved centraliseret ensretning, strukturelle kontrolmekanismer og økonomiske konkurrenceformer, som snarere fremmer egoisme, konflikter, suboptimering og magtkoncentration end samarbejde, udvikling og kreativitet. Konkurrence kan undertiden på kort sigt være gavnlig for at øge aktivitet, indsats og produktivitet. Men at bygge et samfund op på ensidige markedsmekanismer, rå magtanvendelse og de bedst egnedes overlevelse på bekostning af de svageste har historisk set vist sig i længden at være en uholdbar ideologi. Tilsyneladende er vi gennem Konkurrencestatens ideologi på vej til at kopiere nogle af de magtstrukturer og de destruktive »ismer«, som tog overhånd i 1930’erne (Melander 2015).

Heri ligger en såvel etisk som æstetisk udfordring for os alle om at bidrage til det gode menneskesamfund. Dette samfund kan ikke skabes gennem rationelle regler, formelle strukturer, central magtudøvelse og elitære styringsmekanismer. Vi har alle som borgere, politikere, 
administratorer, producenter og fagfolk et ansvar for at bidrage til menneskesamfundets dannelsesprocesser. Dette indbefatter et opgør med Konkurrencestatens instrumentelle samfunds, menneske- og lederskabssyn og en udfordring for økonomistyringens bæredygtighed, lederskabelse og menneskelige dyder.

Artiklen vil i det følgende argumentere for nødvendigheden af de etiske og æstetiske dimensioner omkring samfundets dannelse og organisering. Vi tager først afsæt i de kritiske og skjulte konsekvenser, som Konkurrencestaten såvel socialt, menneskeligt som ledelsesmæssigt har ført til, og som har bragt den danske samfundsmodel i krise (L.B. Caspersen et al. 2015, Melander 2012).

Herudfra vil vi formulere nogle konstruktive ideer til genskabelse af samfundets bæredygtighed, væredygtighed, samskabelse, meningsskabelse og fornyelse. Heri ligger en stor social lederskabsudfordring med nye perspektiver på samfund, organisationer og lederskabelse. Dernæst behandles mere indgående den etiske og æstetiske udfordring til samfundsskabelsen med inspiration fra kunstens, filosofiens og kreativitetens idéverden.

Artiklen sammenfattes til et alternativt syn på lederskab og styring, der sætter fokus på de nære, opsøgende og samskabende værdier tæt på der, hvor mennesker lever og eksisterer, og hvor deres drømme, motivation og indre drivkræfter finder inspiration og kan udfoldes. Til sidst sætter vi fokus på økonomistyringens rolle og ansvarlighed i dette mangfoldige og samskabende samfundsregi. Vi prøver her at formulere nogle nye medierende lederroller for økonomifolket, der lægger op til samskabelse, eksperimenter, iværksætterroller etc. Økonomistyringens indhold sættes ind i et bredere samfundsperspektiv, hvor djøf erne får nye roller som proceskonsulenter, videnformidlere, iværksættere og vogtere af samfundets faglige og demokratiske værdier.

\section{B. Konsekvenserne af økonomiforvalternes overmagt}

\section{De bagvedliggende faktorer}

Der er mange gode grunde til, at økonomistyringens aktører har fået så stor magt i vort samfund. Fagspecialister uanset deres rolle får tildelt særlig strategisk indflydelse, når de i deres rollefag påtager sig opgaver, ansvar og risici, som har afgørende betydning for den organisation eller det samfund, hvis interesser de varetager. I Konkurrencestaten, Vidensamfundet og Velfærdsstaten ses styringen af kapitalens afkast og sikkerhed som den mest betydningsfulde politiske mission for 
samfundets eksistens og uafhængighed, fordi den ses som en betingelse for vores almene materielle velstand og velfærd.

I det repræsentative demokrati og med dets autoritetshierarki er det den økonomisk-politiske sikkerhed og uafhængighed, der legitimerer magtens eksekvering og den fremherskende styringskultur. Betydningen af denne mission er øget i de sidste 30 år som følge af en række sociale og politiske faktorer: Den tiltagende globalisering, de stærke internationale kapitalkræfter, de øgede politiske spændinger mellem den rige og fattige del af verden, den hastige teknologiske udvikling og den deraf følgende konkurrence på viden, innovationskraft og produktionseffektivitet, vidensamfundets tiltagende afhængighed af elektroniske medier og kommunikationsteknologi, nationalstaternes større afhængighed af de store globale kapitalstærke finanscentre, etc.

Vidensamfundets øgede kompleksitet, uklarhed og uforudsigelighed har skabt et særligt domæne for aktører, der evner at håndtere samfundets økonomiske usikkerhed. I den vestlige kultur er det økonomistyringens strateger og forvaltere med baggrund i Konkurrencestaten, som udgør den store synlige garant for at sikre fællesskabets fremtidige velfærd. Det er Velfærdssamfundet, der således legitimerer Konkurrencestaten, og som igen producerer de uendelige styringsreformer og risikoaverse styringsregimer. Men denne politiske sammenhæng er samfundsskabt og har utilsigtede sociale konsekvenser, som vi som borgere bør modarbejde.

\section{De sociale konsekvenser af forvalternes overmagt}

Stort set overalt i samfundet har forvalterne fået mere magt på bekostning af de fagprofessionelle. I reformprocesserne har forvalterne ofte overtal i de afgørende beslutningsfora, hvilket betyder en skævvridning af beslutningsprocesserne med undervurdering af de relevante og vigtige faglige aspekter. Det kan samfundsmæssigt have betydning for samfundets samlede problemløsning. Nogle af de uheldige virkninger heraf ses i de mange kritiske sager og fejl i centraladministrationen.

Den centrale satsning på samfundets økonomiske sikkerhed har store konsekvenser for samfundets specialisering, magtfordeling, demokratiske forankring, den økonomiske ligestilling og de ledelsesmæssige udfordringer i styringens konfliktfelter. De øgede krav til aktørernes kompetencer og specialistviden og produktionens effektivitet stiller store krav til aktørernes 
styringsindsats, eftergivenhed og indordning. Afhængigheden af forvalternes styringsviden og ledelsesmæssige færdigheder har afgørende betydning for samspillet mellem ledere og forvaltere, samt de faglige producenters motivation. Fagfolkene har traditionelt set haft stor magt, men som følge af statens stigende krav om økonomisk effektivitet har forvalterne øget deres relative magt. Dette skaber et ledelsesmæssigt konfliktfelt mellem de faglige producenter og de styrende økonomifolk, hvor budgetpres og koordination ofte går ud over fagfolkenes faglige stolthed og håndtering af deres faglige mission. Dette skaber konflikter og følelse af manglende anerkendelse hos de ansvarlige fagfolk. Dette afstedkommer et øget behov for lederkompetencer hos både fagfolk og forvaltere, som ofte har modsatte interesser og taler forskellige sprog. Ledelsesfeltet efterlader et åbent rum af kompleksitet, konflikter, dilemmaer og paradokser. Dette felt er rammende blevet kaldt for »desperate governance«.

I vort højtspecialiserede samfund stiller staten krav til den enkelte om at være veluddannet, arbejdsom og loyal over for fællesskabets præstationskrav fra fødsel til død. Arbejde og kompetencer er afgørende for at være fuldgyldigt medlem af fællesskabet. Men Konkurrencestatens centrale krav til den enkeltes ansvarlighed og loyalitet skaber pres på menneskers deltagelse i det indbyrdes allestedsværende faglige og produktive præstationsræs og kampen for faglig accept og anerkendelse. Systemets sociale kontrol og ensretning vil her føre til øget fremmedgørelse, større social og økonomisk ulighed, øget stress, flere tabere, flere ekskluderede, flere psykisk og fysisk syge etc. Konkurrencestaten er en dyr samfundskonstruktion for os alle. Den signalerer en effektivitet, som er forførende, men som den reelt ikke kan leve op til.

\section{Der er behov for et modspil til forvalternes og magtelitens magtudøvelse}

I dag må vi konstatere, at den højt besungne danske demokratiske samfundsmodel er i opløsning, fordi det fælles oplevede samfundsejerskab og den lille magtdistance er på kraftig retur. Prisen for den globale konkurrencekraft og den ensidige styring på effektivitet, bundlinje og den enkeltes præstationer, talenter og fortrin har taget overhånd. I et repræsentativt demokrati har vi alle et ansvar for, at vi ikke ender i et opbrudt samfund af kaos og meningsløshed. Økonomerne, forvalterne, juristerne og djøf' erne har vi tildelt de afgørende lederroller og magtbeføjelser til at sikre systemets globale økonomiske fremdrift. Men hvordan kan vi ændre denne udvikling mod et samfund, der i stigende grad står i modstrid med menneskers basale behov for udfoldelse, trivsel, accept, mening og kærlighed? Jo flere mennesker, vi inkluderer i systemet, desto flere føler sig 
ekskluderet. Mange ledere, forvaltere, politikere, samfundsdebattører og almindelige borgere kan se tendenserne, men de fleste føler sig magtesløse eller lukker øjnene for realiteterne. Politikerne har svært ved at håndtere samfundets sociale udfordringer, fordi de qua deres nedarvede roller kun magter at finde administrative løsninger i form af nye regler, systemer og strukturer. Og det gør kun centralismen, distancen og fremmedgørelsen værre. Heri ligger de store udfordringer for økonomifolkets ledelseskompetencer, når systemets kompleksitet og paradokser skal håndteres på en bæredygtig og væredygtig måde. En sådan udfordring af økonomifolkets magt kræver accepten af et bredere socialt og bæredygtigt lederansvar, hvor andre overliggende humanistiske værdier og sociale hensyn kommer på banen. Det stiller krav til ledernes og administratorernes etiske og æstetiske ansvarlighed.

\section{Behovet for et bredere samfunds- og menneskesyn i økonomistyringen}

Ethvert fagspeciale har i vort komplekse samfund behov for at inddrage samfundsmæssige og menneskelige aspekter i sin fagspecifikke ledelsesoptik. Dette samfundsansvar er vigtigt, fordi et hierarkisk og teknokratisk styret samfund ofte har store strategiske tilpasningsproblemer, fordi aktørerne mangler værdimæssige og holdningsmæssige holdepunkter. Imperier er set i et historisk tilbageblik gået til grunde, fordi de var baseret på en ensidig og snæver ideologi, der ikke tillod en åben debat, grænseoverskridende ideer, menneskelige hensyn etc. Et pluralistisk samfund, hvor der er »højt til loftet«, og hvor kunst, fiktion, fantasi og satire får lov til at udfolde sig, vil fungere som et mere robust og fleksibelt samfund, fordi værdiskabelse, meningsdannelse, kreativitet og ledelsesudvikling ikke udsættes for ensidig ensretning og kontrol.

\section{Hvorfor har etik en vigtig samfundsskabende funktion?}

Etisk ansvarlighed med deraf følgende social og kulturel dannelse har afgørende betydning for udviklingen af såvel hele samfundet som dets organisationer og borgere. Etik har stor betydning for den måde, vi leder og styrer på. Etik handler om at behandle andre ud fra det godes fremme, dvs. ud fra hensynet til såvel andre mennesker som til sociale fællesskaber, som bærer fællesskabet som helhed. Vi taler f.eks. i dag om »det gode samfund«, »den etiske fordring«, »aktørbaseret ledelse« etc.

Det er vigtigt her at stille spørgsmål til, i hvilket omfang de etiske dimensioner reelt sættes i fokus, når vi arbejder med virkelighedens management, styringstanker og det bagvedliggende samfunds- og menneskesyn. Mange mennesker er i dag i vildrede med, hvad der er meningen med 
deres liv som borgere, producenter og ledere, fordi deres udfoldelse begrænses af samfundets regler og normer, og fordi omgivelserne og mediebilledet ændrer sig med stor hast. De lever i et absurd, fragmenteret og usammenhængende univers. Medierne er segmenterede, åndløse og uden bredere holdepunkter. Modtagernes udsyn påvirkes i alle retninger af kortsigtede modestrømninger. Det gør det svært at orientere sig. Vi har i dag ikke et fælles sprog, som har indhold, vingefang, dybde, udsyn og nærhed til at udtrykke vores behov for at finde nye fælles sociale holdepunkter.

Etik udgør en grundlæggende værdi for et samfunds opretholdelse, sammenhængskraft og udvikling til sikring af det fælles bedste. Etik handler om det gode liv, den retfærdige handling og menneskers værdighed og væredygtighed. Det godes etik er både anvisende og problematiserende - den hjælper os til rette i en verden fyldt med uklare beslutninger og valg og udfordrer vort syn på verden. Etik er den selvlovgivning, der giver os frihed, men også holdepunkter. Etik giver forstyrrelse og må ikke reduceres til almene floskler, men tværtimod turde opskrives i en modstand mod vore tilbøjeligheder. Etiske kodekser skal holde os fast på et formål med en række principper, der er større end det enkelte valg. Etiske værdier skal præsentere en stræben og være motiverende for den gode handling. Derfor er den etiske fordring (Beck Jørgensen 2014) vigtigere end den økonomiske bundlinje og den finansielle sikkerhed, som i dag synes at være blevet vores overordnede rettesnor (Løgstrup 1956/95). Etik udgør grundlaget for menneskers samvær og samspil. Etik er et blandt flere dannelsessprog, værdier og udsyn, der sammen med f.eks. æstetikken skaber forskellen på mennesker og dyr.

\section{Vi taler meget om tillid og fælles værdier, men de er svære at praktisere}

Vi er i dag meget optaget af, hvor vigtigt det er, at mennesker har tillid til hinanden. Måske fordi vi netop oplever øget mistillid og spin, som ikke bringer samfundet videre. Hvis der ikke eksisterer gensidig tillid mellem et samfunds aktører, dvs. politikere, forvaltere, fagprofessionelle, medborgere etc., bryder samfundet sammen. Etik er en afgørende egenskab for, at et samfund kan hænge sammen og overleve såvel socialt som økonomisk og funktionelt. Det gælder ikke mindst, fordi borgerne skal have tillid til, at f.eks. staten og dens magthavere vil dem det godt. Et såkaldt velfærdssamfund kan ikke udvikle sig, hvis borgerne ikke har tillid til staten, dets ledere, forvaltere, videnbærere etc. Derfor er det et problem, hvis vi som borgere ikke har tillid til politikerne og deres evne til at udmønte samfundets værdier til fælles bedste. Hvis vi f.eks. føler, at den politisk-administrative elite ikke udfolder samfundets muligheder på en bæredygtig og 
retfærdig måde, vil et samfund have svært ved at realisere sin velfærdsmission. Derfor giver etikken anledning til refleksion og forandring.

\section{Hvor kommer etikken fra?}

Etik er et udslag af nedarvede religiøse, sociale og medmenneskelige værdier og dannelsessyn, som indgår i alle kultursamfunds basale gener. Alle verdensreligioner har f.eks. et etisk eksistentielt og menneskeligt værdisyn, selvom de er meget forskellige og fortolkes politisk på mange og ikke særligt menneskeværdige måder. Vore skandinaviske protestantiske samfund bygger på et etisk humanistisk grundlag, som fortsat præger vort menneskesyn, arbejdssyn, de fælles kulturelle værdier, vort uddannelsessyn, det fungerende folkestyre, vore ledelsesværdier etc. Den såkaldte danske (eller rettere skandinaviske) samfunds- og organisationsmodel har stærke rødder i vores religiøse og folkelige værdisyn. Tænk f.eks. på grundtvigianismen, højskolerne, agrarsamfundet, andelsbevægelsen, arbejderbevægelsen etc., som stadig udgør grundpillerne for vort demokratiske fællesskab. Der er dog i dag tendenser i det globale postindustrielle samfund, som synes at bryde med disse nedarvede relationelle og sociale værdier.

Den hastige teknologiske udvikling og den tiltagende dyrkelse af individuelle færdigheder, særegne kompetencer og unikke talenter har skabt et videnbaseret teknokrati, hvor konkurrenceevne, økonomisk kapitalkraft, mediekraft og materielle værdier styrer samfundets sociale og politiske udvikling. Dette har på en række områder sat fællesskabets etiske, kulturelle og menneskelige værdier ud af kraft. Vi har fået et åndløst og splittet samfund præget af en centralistisk stat styret af ensidige globale markedskræfter, bureaukratiske regler, usammenhængende og specialiseret ekspertviden, der udfoldes ukritisk og destruktivt og uden et etisk dannelsesperspektiv. Vi har fået et idéløst systemsamfund, hvis kvalitetskriterier alene skal søges i materielle resultater, evige og tomme innovationsprocesser og individuelle præstationer. Vi står i dag med et stort dilemma, fordi Velfærdsstaten og Konkurrencestaten har umuliggjort det fælles ejerskab til samfundet. Produktivitet, præstationer og konkurrence har fortrængt det gode samfunds relationelle og meningsfulde værdier uden blik for en større idé eller fælles vision. Staten - og måske dermed også samfundet og kulturen - er i færd med at kappe alle bånd til fortællinger, der er større end statens eller organisationens økonomiske overlevelse. Alt sammen med henvisning til nødvendighedens politik og centreret i et splittet regime, der først og fremmest bekymrer sig om sin egen overlevelse. Der savnes et samfundsledelsesperspektiv, der giver fælles mening og værdi. Et sådant samfund har svært ved at overleve på lang sigt. 
Som eksempel på religionens etiske påvirkning skal her blot nævnes de værdier, som Paulus gennem sine breve formanede mennesker til at følge: Mennesker skal ikke være selvpromoverende, men bevidste om og loyale over for de fælles relationelle værdier. De bør derfor ikke være indbildske og selvretfærdige og således udfordre eller misunde hinanden. Samfundets goder er ganske vist ujævnt fordelt, men hvert menneske har sin egen værdi. Til »åndens frugter« regnede Paulus derfor tålmodighed, trofasthed, ydmyghed og selvbeherskelse. Det er interessant at konstatere, at nogle af disse grundlæggende etiske værdier faktisk i høj grad kan genfindes i nogle af de overordnede samskabelsesideer, som i dag ivrigt debatteres og indgår i nyere samfundsideer og ledelsesideologier som Compliance, Scharmers U-teori, Staceys processuelle organisationssyn etc. Men i økonomistyringens logik har disse værdier kun begrænset betydning.

\section{4. Økonomistyringens aktuelle styringskoncepter går desværre den stik modsatte vej}

Over for den etiske værdiskabelse står de teknokratiske værdier, som ligger bag den markedsfokuserende og præstationsstyrede Management stat. Hvis vi således sammenligner Paulus ord med de forskrifter, som Konkurrencestaten fungerer på, møder vi stort set det modsatte syn på samfundets værdier og spilleregler. Organisationer forventes her at være utålmodige, omskiftelige og under stadigt opbrud, jævnfør f.eks. disruptionsideologien.

I de fleste moderne managementteorier indgår foranderlighed og innovation som et mantra og et afgørende krav, næsten som en værdi i sig selv. Organisationer skal derfor ikke være ydmyge og beskedne, men snarere være selvforherligende og selvpromoverende og markedsføre og brande sig selv på bekostning af de andre. Konkurrence anses for at være noget positivt og ses i dag som afgørende for samfundets fortsatte fremdrift og magtkoncentration. Samarbejde og netværk er noget man taler om, men som man ikke reelt handler efter (Holmblad Brunsson 2011). For det fremmer ikke magtudøvelsen. I den institutionelle og strategiske økonomistyringsteori træffes alene målrettede beslutninger, dvs. handlinger, der alene gavner organisationen og én selv. Her udgør markedet den grundlæggende logik.

\section{Samfundets etik smitter af på menneskers adfærd og lederskab}

Samfundets etiske værdier smitter naturligvis af på de mennesker, der handler og omgås inden for organisationen. Kravet om organisationers egoisme får afgørende konsekvenser for relationen 
mellem mennesker både i organisationer og samfund. Der er således noget næsten hyklerisk og usandt i den måde, vi i dag taler om og praktiserer relationer og værdier mellem mennesker i vore organisationer og samfund. Vi siger ét, men handler på modsat vis. Selvrealisering er jo den vigtigste motivationsfaktor.

I de store globale deklarationer om menneskerettigheder, der foreskriver frihed, lighed og de samme rettigheder for alle, er der heller ingen begrænsninger eller tvivl. Men i praksis ude i samfundet bliver mennesker tillagt forskellig værdi og behandles ud fra statens krav og magthavernes forgodtbefindende. I organisationer bliver mennesker tildelt bestemte roller, låst inde i afgrænsede institutioner og styret af kontrollerende regler og rammer. Mennesker bliver udsat for forskellig tilgang til ressourcer, rigdom og belønninger. De fleste mennesker i verden lever i fattigdom og under vilkår, som de ikke selv er herrer over eller kan slippe ud af for egen kraft. På denne måde opstår der konflikter mellem organisationers og menneskers behov, interesser og rettigheder. I virkeligheden må mennesker i høj grad indordne sig samfundets og organisationers snævre økonomiske og politiske betingelser. Etik på samfunds- og organisationsniveau adskiller sig på alle måder fra menneskers individuelle etik og deres indbyrdes sociale relationer. Dette udgør en væsentlig baggrund for at forstå organisationers og menneskers etiske værdier og relationer i såvel teorien som i praksis. Vi må konstatere, at der er en evig konflikt mellem de officielle deklarationer og den skinbarlige sociale praksis. Dette paradoks er i høj grad afgørende for de store globale konfliktproblemer, som vi i stigende grad er vidner til i vor tid.

\section{Fagprofessioners magt er en konsekvens af samfundet}

Når vi ser på den måde, vi i organisationer håndterer etik på i praksis, må vi konstatere, at mange etiske normer er funderet i menneskers intellekt og i deres sociale, kulturelle og uddannelsesmæssige baggrund. Enhver fagprofession har sine egne faglige, sociale og etiske normer. Man kan sige, at fagprofessionernes magt netop er karakteriseret ved de faglige normer, etiske værdier og den nedarvede selvforståelse, som de har tillært sig og fået socialt indarbejdet under deres studier. Disse værdier vil ofte være ekskluderende i forhold til andre, der ikke har den samme faglighed. Fagfolk uddannes således til at skabe et konfliktproblem, fordi de ikke får tilegnet sig et socialt og mangfoldigt dannelsesgrundlag. Vort præstationsrettede uddannelsessystem lægger fokus på færdigheder og ikke på dannelse. Herved skabes et alvorligt demokratisk samfundsproblem, som politikerne underkender og ligefrem understøtter. 
På samfundsplan sker der til stadighed forskydninger i fagfolkenes relationelle magt. I vort regelog økonomistyrede samfund har jurister, økonomer og politologer fået tillagt en utrolig magt, fordi de sidder tæt på de afgørende politiske magtcentre og beslutningsfora. Det gælder stort set indenfor alle styringsniveauer og sektorer.

Inden for staten er antallet af økonomer og jurister i departementer og styrelser steget betydeligt indenfor de sidste 40 år set i forhold til andre akademiske og faglige grupperinger. Dette skyldes flere ting. Dels at samfundets institutionelle strukturer og beslutningsopgaver er tiltaget i omfang og kompleksitet. De såkaldte »regnedrenge« og »budgetbisser«i Finansministeriet har tiltaget sig en helt utrolig overmagt og dominerer statens politiske beslutninger såvel direkte som indirekte. Dette forstærkes af, at politikerne i Folketinget også i stigende grad er blevet rekrutteret fra de forvaltningsmæssige akademiske uddannelser, og fordi politikernes afhængighed af forvaltere er øget.

Man kan også se, at der er tale om en selvforstærkende virkning derved, at mange stillinger på de lavere niveauer besættes af jurister og økonomer, fordi det styrker de lokale beslutningsprocesser, at man har folk, der fagligt, kompetencemæssigt og politisk matcher de centrale beslutningstagere længere oppe i hierarkiet. Tilsvarende skævvridning præger også interesseorganisationernes ledelsesfunktioner, hvor antallet af akademikere som økonomer, politologer og jurister stiger på bekostning af andre fagfolk.

Djøf erne har overtaget magten på bekostning af de andre fagprofessioner som de tekniske, medicinske, naturvidenskabelige og humanistiske områder. Der er derfor brug for en bredere og kritisk selvrefleksion blandt styringsfolket over den ensidige magtkoncentration og topstyring. Denne selvrefleksion må bygge på en fælles erkendelse af nødvendigheden af en bred etisk forståelse af samfundets værdier, der ligger udover det rationelle funktionelle forvaltningsperspektiv.

\section{Fremtidens udfordringer for økonomistyringens professionelle}

Vi mener som de fleste, at Djøf iseringen har taget overhånd. Vi mener også, at denne form for magtkoncentration og systemovermagt ikke kan opretholdes i længden. Forvalternes overmagt er 
i høj grad samfundsskabt og kulturbåret, men er på mange måder dysfunktionel, fordi den ikke fremmer det gode samfunds almene værdier. Djøf erne må derfor tåle at blive modsagt og underkastet kritik både udefra, indefra og forhåbentligt også oppefra. Men det sidste kræver et politisk systemskifte. Men det bedste ville være, at de som fagfolk selv forholdt sig kritisk til de åbenbare sociale konsekvenser, som dagligt kommer til udtryk i de mange sociale samfundsproblemer og fejl, som er synlige for enhver. Når andre fagprofessioner som f.eks. læger og arkitekter i mange tilfælde inddrager andre sociale hensyn i deres ledelsesadfærd end de fagspecifikke, er det vel også muligt for økonomer og jurister. Men tilsyneladende er der mange Djøf er, der fejlagtigt ser sig selv som samfundsorienterede generalister, der anlægger et balanceret helhedssyn. De er opdraget til at se sig selv som systemets usårlige garanter.

Alle fagfolk uanset speciale bør påtage sig et etisk og socialt ansvar for deres ensidige indflydelse på samfundets udvikling og de velfærdsproblemer, systemfejl og de skæve beslutninger, som træffes fra centralt hold. Det må være borgerne, der må vurdere, om balancen er til stede. Det er derfor nødvendigt, at man i et demokrati accepterer at blive modsagt, at man fordeler magten mellem flere politiske videnfelter og åbner op for andre fagfolks alternative viden, meninger og samfundssyn.

\section{Fremtidens synlige lederskabelse udfordrer økonomifolkets identitet}

Vi vil som samfundskritikere og tilhængere af et dialogbaseret, relationelt og demokratisk samfund anbefale, at der inddrages etiske og humanistiske værdier i den måde, vi designer vores samfundsudvikling på. Den økonomiske markedslogik, den bureaukratiske systemtænkning og det evidensbaserede teknokrati kan ikke alene skabe et bæredygtigt og væredygtigt relationelt menneskesamfund. Der ligger her et stort ansvar for de forsknings- og undervisningsinstitutioner, der uddanner fagfolk, herunder økonomer, jurister og politologer. I vort specialiserede vidensamfund magter vi kun i begrænset omfang at inkludere alternative samfunds-, menneske- og metodesyn i vores videngrundlag. Vi er primært optaget af at dyrke og styrke snævre færdigheder, specialisering, ekspertiser og faglige eliter. Statens pres på universiteterne for at reducere de studerendes studietid og øge den læringsmæssige fremdrift har som uheldig konsekvens en tiltagende faglig ensidighed og overfladiskhed med mangel på social og kulturel dannelse og værdimæssig pluralisme. Her udgør »hybridledelses«-modellen kun en lille krusning i den ensrettede og enfoldige malstrøm. Men lederskabets generalister kan jo have mange motiver til at inddrage ikke-faglige rationaler i deres lederadfærd. Som eksempler kan 
nævnes karrieremæssige, sociale og politiske motiver, som nok pynter på magtskalaen, men som ikke nødvendigvis styrker lederens etiske værdier. Så en deklaration af lederskabets mangfoldighed er ikke nok. Det skal give sig udslag i et bredere kulturelt båret og etisk alternativt menneske- og samfundssyn. Så der er lang vej endnu.

\section{Nogle udfordringer for økonomistyringens praksis}

Lad os til sidst opregne nogle relevante refleksioner om økonomistyringens fremtidige lederskabssyn i praksis (med inspiration fra debatten om Lederskabsreformationen og SACREbevægelsen $)^{3}$

1. Vi bør alle som borgere (politikere, ledere, forvaltere, fagfolk, videnskabere, kunstnere, meningsskabere etc.) værne om det demokratiske fællesskab, som vi alle er en del af, og som er under kontinuerlig forandring

2. Vi må mobilisere, samle, udfordre og udfolde alle de kreative og relationelle kræfter synlige som skjulte - mod at skabe et bæredygtigt og væredygtigt demokratisk samfund på trods af de mange ensrettende faktorer, der synes at arbejde imod denne vision

3. Styring og ledelse bør kun udfoldes af frie og engagerede mennesker, der føler et ejerskab til og et ansvar for samfundet og forstår de dannelseskræfter, der skal til for at realisere et samfund til fælles bedste

4. Det handler om at få øje på og fokusere på de uendelige muligheder, som forskellige mennesker i samspil og gennem processer har for at skabe værdi, fællesskab og foranderlighed på trods af den sociale mangfoldighed og de uendelige interne modsætninger i det åbne menneskesamfund

5. Kunstens kraft og kulturlivets multiple værdisyn kan give vigtig inspiration gennem forbilleder, idealer og refleksionsstilgange (jf. SACRE-bevægelsen)

6. Der eksisterer i dag i vort komplekse og risikoaverse reform- og præstationssamfund en overvægt af regler, rammer og ressourcebegrænsninger, der i højere grad fokuserer på trusler, usikkerhed og farer end på de uendelige relationelle muligheder for at realisere det gode samfund. Dette perspektiv af opbrud og risici dominerer i dag samfundets organisationer og virksomheder og præger styringens arbejdsformer, institutioner, samspil, metodesyn og tankesæt. Hermed fremmes angst, ensretning, meningsløshed, perfektionisme, rationalitet og funktionalitet til skade for livsudfoldelse, lyst, leg, kreativitet, entusiasme og grænseoverskridende samspil (Melander 2014) 
7. Lederskab og styringsrationaler er anerkendte faktorer for institutioners effektivitet og ressourceudvikling, men styringens rationalitet og instrumentelle tilrettelæggelse må ikke indsnævre og ensrette mennesker evne til at opsøge og forholde sig til den nære virkelighed, de skjulte forestillede og uudfordrede mulighedsrum, det åbne univers af ukendte og umulige muligheder etc.

8. Styring har i dag en tendens til at fokusere på at måle, veje og beskrive det, som vi har tradition for at gøre måleligt, men derved ses der bort fra de sociale og skjulte forhold, som er svære at kvalificere, og som til gengæld har størst betydning for samfundets værdiskabelse. F.eks. er faktorer som dannelse, relationer, tillidsskabelse, kreativitet, værdighed og udsyn umuligt at måle, men ikke desto mindre er de afgørende for samfundets sammenhængskraft og menneskers lykke. Det er derfor en alvorlig fejl at se bort fra dem i ledelsesprocessen.

\section{E. Afslutning}

Et alternativt menneske-, samfunds- og lederskabssyn vil grundlæggende kunne ændre det konventionelle og materialistiske syn på økonomistyringens mission, organisation, metodesyn, funktionalitet og tællelighed. Den neoklassiske markedsorienterede beslutnings- og optimeringslogik bør erstattes eller suppleres med et bredere mere mangfoldigt organisations- og lederskabssyn, hvor de strategiske perspektiver inddrager flere sociale, situationsbestemte og erfaringsbaserede aspekter. Således er styringens indhold og form i sig selv genstand for debat og bør ikke være låst fast af universelle faglige, politiske og metodemæssige bindinger.

Når styringens design f.eks. alternativt inddrager de etiske og æstetiske aspekter og gør feltet mere åbent i forhold til samfundets almene sociale, politiske og kulturelle udviklingsdiskurs, bliver styringen en konsekvens af aktørernes refleksioner og organisationers fokale transformationsprocesser som modspil til den sociale kontekst. Økonomistyringens organisatoriske design vil altid blive til i spændingsfeltet mellem på den ene side statens og systemets institutionelle og ensrettende rationalitetslogik og på den anden side menneskesamfundets behov for almen og relationel mangfoldighed og individuel normtilpasning til det lokale kulturelle og uudforskede miljø. Denne politiske konfrontation bliver interessant at følge i de nærmeste år, hvor statens og elitens politiske ensretning bliver sat til debat og kommer under pres. 


\section{Litteratur}

Alvesson, Mats; Spicer, André (forfatter og red. ) 2011. Metaphors we lead by, understanding leadership in the real world. London; Routledge

Arendt, Hannah. 1963. Eichmann in Jerusalem. A Report on the Banality of Evil. London \& Faber $\&$ Faber

Arendt, Hannah. 1958. The Human Condition. Chicago. University of Chicago Press

Beck, Ulrich.1997. Risikosamfundet: på vej mod en ny modernitet. København; Hans Reitzel

Beck Jørgensen, Torben. 2014. Menneskeopfattelser, offentlig styring og den etiske udfordring.

Oplæg ved CVL konferencen 27. november 2014

Brandt, Preben. 2012. Udenfor. Erindringer fra et liv på kanten. København. Kristeligt dagblads forlag

Brunsson, Nils. 2006. Mechanisms of hope: maintaining the dream of the rationel organization.

Copenhagen; Copenhagen Business School Press

Cameron, Kim S.; Quinn, Robert E. 2006 rev.udg. Diagnosing and changing organizational culturebased on the competing values framework. San Francisco; Jossey-Bass

Christensen, Søren; Daugaard Jensen, Poul Erik. 2001. Kontrol i det stille. Om magt og deltagelse.

København; Samfundslitteratur

Deleuze, Gilles and F. Guattaris. 1987. Mille Plateaux. Capitalisme et Schizophrénie. Paris

Dryzek, John S. 2000. Deliberative democracy and beyond, liberals, critics, contestations. Oxford; Oxford University Press

Foucault, Paul Michel. 1966/2000. Ordet og tingene. En arkeologi over videnskabelse om mennesket. København

Fromm, Erich. 2001. The fear offreedom. London; Routledge

Gotfredsen, Sørine. 2011. Den åndløse dansker. København. Kristeligt Dagblads Forlag

Griffin, D. \& Ralph Stacey. 2005. Complexity and the Experience of Leading Organisations. London. Routledge

Grint, Keith. 1997. Fuzzy management. Contemporary ideas and practices at work. Oxford; Oxford University Press. https://doi.org/10.1093/acprof:0so/9780198775003.001.0001

Grint, Keith. 2005. Leadership: Limits and possibilities. London, Basingstoke; Palgrave MacMillan. https://doi.org/10.1007/978-1-137-07058-6

Habermas, Jürgen. 1996. Between facts and norms, contribution to a discourse theory and democracy. Cambridge, Polity Press 
Hardt, Michael; Negri, Antonio. 2003. Imperiet. Kbh.; Informations Forlag

Hildebrandt, Steen. 2014. Vækst og bæredygtighed. Valby. Libris Business

Holmblad, Karin Brunsson. 2011. Den företagsekonomiske etiken I: Økonomistyring \& Informatik, 26. årgang nr. 5

Kaspersen, Lars Bo og Jan Nørgaard. 2015. Ledelseskrise i Konkurrencestaten. København. Hans Reitzels Forlag

Kellerman, Barbara. 2008. Followership. How followers are creating change and changing leaders. Boston, MA; Harvard Business School Press

Kemp, Peter. 2015. Menneskets opløsning i markedet. Essay i »Tag etikken tilbage« red. Mikkel Wold m.fl.

Kierkegaard, Søren. 1963. Begrebet Angest, i: Samlede varker; bind 6, pp.101-240. København; Gyldendal

Kirkeby, Ole Fogh. 2011. Om velferd. Det godes politik. København; Gyldendal Business.

Korsgaard, Ove. 2004. Kampen om folket. Et dannelsesperspektiv på dansk historie gennem 500 år. København; Gyldendal

Luhmann, Niklas. 1999. Tillid - en mekanisme til reduktion af social kompleksitet. Kbh.; Hans Reitzel Lomholt, Karen og Jonas Norgaard Mortensen (red.) 2015. Det relationelle menneske. Personalisme $i$ perspektiv (antologi, Vindelsti, Frederiksværk)

Løgstrup, K.E. 1956/91. Den etiske fordring. København. Nordisk Forlag

March, James G. 2008. Fornuft og forandring. Ledelse i en verden beriget med uklarhed. Frederiksberg; Samfundslitteratur

Melander, Preben. 2012. Lederskabsreformationen. Kampen for et demokratisk samfund som modspil til det globale imperium. København; Jurist- og Økonomforbundets Forlag

Melander, Preben. 2015. Menneskers værdighed og livsudfoldelse er begrænset af statens ensrettede styringslogik og tomme menneskesyn I: Økonomistyring \& Informatik. 31. årgang nr. 1

Melander, Preben (red.) 2008. Det fortrangte offentlige lederskab. Om offentlig ledelse efter New Public Management. København; Jurist- og Økonomforbundets Forlag

Melander, Preben (red.) 2014. Laboratorier til baredygtig samfunds- og lederskabelse - Når lederskabelse samskabes af mennesker. København. Jurist- og Økonomforbundets Forlag Melander, Preben. 1996. Økonomistyring i politisk styrede organisationer. Konfrontationen mellem økonomisk rationalitet og andre vardisystemer. København; Jurist- og Økonomforbundets Forlag 
Molin, Jan. 2002. Den indfoldede orden - den udfoldede praksis. København; Nyt fra Samfundsvidenskaberne

Nørreklit, Lennart et al. 1986. Aktørsmetoden Aalborg Universitet

Pedersen, Ove Kai. 2011. Konkurrencestaten. København; Hans Reitzel

Power, Michael. 1997. The audit society, Rituals of verification. Oxford; Oxford University Press Scharmer, Carl Otto. 2009. Teori U - lederskab, der åbner fremtiden. Hinnerup; Forlaget Ankerhus Schiller, Herbert I. 1996. Information Inequality, the Deepening Social Crisis in America. New York; Routledge

Skytte Jakobsen, Marianne, Niels Ejersbo og Mickael Bech. 2015. Faglig, hybrid eller generalist ledelse i sundhedsvæsenet. Et studie af ledende overlæger i Danmark I: Økonomistyring ${ }^{\circ}$ Informatik, 31. årgang, nr. 2

Stacey, Ralph D. 2010. Complexity and Organizational Reality. Uncertainty and the Need to rethink Management after the Collapse of Investment Capitalism. London; New York; Routledge

Taylor, Charles. 1994. Multiculturalism, examing the politics of recognition. Princeton; Princeton University Press

Thygesen, Niels; Vallentin, Steen; Raffnsøe, Sverre. 2008. Tilliden og magten. Om at lede og skabe vardi gennem tillid. København; Børsens Forlag

Thyssen, Ole; Dahl, Henrik. 2008. Krigeren, Borgeren og Taberen. Kbh.: Gyldendal

Verweij, Marco; Thompson. M. 2006. Clumsy solutions for a complex world: governance, politics and plural perceptions. London; Basingstoke; New York; Palgrave Macmillan

Weick, Karl E.; Sutcliffe, Kathleen M. 2007. Managing the unexpected. Resilient performance in an age of uncertainty. Chichester; John Wiley

Wold, Mikkel (red.) et al. 2015. Tag etikken tilbage - Markedstankningen og dens konsekvenser. København. Jensen \& Dalgaard

\footnotetext{
${ }^{1}$ Artiklen er en relancering af artikel bragt i Per Nikolaj Bukh \& Thomas Borup Kristensens (red.) Produktion og styring - Perspektiver på økonomistyringen. Festskrift til Poul Israelsen, publiceret af Jurist- og Økonomforbundets Forlag i 2016.

${ }^{2}$ Aktørsmetoden fra 1980’erne kan ses som det første opgør med den rationelle og markedsorienterede metodetilgang og økonomistyringens nytteorienterede menneskesyn. Den havde sin basis ved Aalborg Universitet og var båret af Lennart Nørreklit, Hanne Nørreklit og Poul Israelsen (Nørreklit et al. 1986)

${ }^{3}$ SACRE-programmet og -bevægelsen er et forsøg på at skabe en bredere bevidsthed om fremtidens samfundsskabelse med basis i kunstens, kulturlivets og filosofiens alternative tankesæt og musiske og magiske sprog. Se mere på http://sacre.cbs.dk/cvl
} 